\title{
Crown-fibre attribute relationships for enhanced forest inventory: Progress and prospects
}

\author{
by Arthur Groot ${ }^{1 *}$, Francesco Cortini² and Michael A. Wulder²
}

\begin{abstract}
A five-year project, Crown-Fibre Attribute Relationships (CFAR), was completed by the Canadian Wood Fibre Centre (Natural Resources Canada) to explore the relationships between tree crown characteristics and wood fibre attributes. The CFAR project used a number of data sets distributed across Canada (e.g., silvicultural experiments), providing a range of crown conditions following spacing and thinning treatments. The approaches developed under the CFAR project, along with other relevant research, indicate that is possible to enhance current forest inventories by providing estimates of fibre attributes from crown characteristics of individual trees that can, or are poised to be, captured using remotely sensed data. Predictability was related to the dimensionality of the fibre attributes with models for zero-dimensionality fibre attributes (e.g., DBH) showing RMSE of $10 \%$ to $15 \%$ of mean values. Also, one-dimensional (e.g., sapwood area) and two-dimensional (i.e., ring area) models quantified longitudinal patterns with low bias. Current values of wood density were not related to crown characteristics; instead, recent research suggests that wood density is regulated by hydraulic and biomechanical constraints. Further evolution of remote sensing technology and related research will help to address the temporal problem posed by two- and three-dimensional fibre attributes.
\end{abstract}

Key words: Canadian Wood Fibre Centre, crown-fibre attribute relationships, DBH, maximum branch diameter, sapwood area, ring area, wood density, tree crown, LiDAR

\section{RÉSUMÉ}

Un projet d'une durée de cinq ans portant sur les relations entre la cime des arbres et les qualités de la fibre a été complété par le Centre canadien sur la fibre de bois (Ressources naturelles Canada) et avait pour objectif détudier les relations entre les caractéristiques de la cime des arbres et les qualités de la fibre du bois. Le projet a utilisé plusieurs ensembles de données provenant d'un peu partout au Canada (par ex., des expériences sylvicoles) et représentant plusieurs conditions de cime à la suite de traitements de dégagement et déclaircie. Les approches élaborées dans le cas de ce projet, ainsi quau cours de travaux de recherche connexes, indiquent qu'il est possible d’améliorer les inventaires forestiers actuels en ajoutant un estimé des qualités de la fibre à partir des caractéristiques de la cime de chaque arbre qui peut être, ou qui serait sur le point dềtre saisies par télédétection. La prévisibilité a été liée à la dimensionnalité des qualités de la fibre ayant des modèles sans dimensionnalité (par ex., dhp) et affiche une erreur quadratique moyenne (RMSE) de $10 \%$ à $15 \%$. De plus, des modèles unidimensionnels (par ex., la surface de l’aubier) et des modèles à deux dimensions (par ex., la surface des anneaux de croissance) ont permis de quantifier les profils longitudinaux avec un faible biais. Les valeurs actuelles de la densité du bois nont pas été reliées aux caractéristiques des cimes, mais cependant, une recherche récente laisse entendre que la densité du bois découle de contraintes hydrauliques et biomécaniques. Les prochains développements des techniques de télédétection et des recherches connexes permettront de résoudre la problématique du temps posée par les qualités bidimensionnelles et tridimensionnelles de la fibre.

Mots clés : Centre canadien sur la fibre de bois, relations entre la cime et les qualités de la fibre, dhp, diamètre maximal des branches, surface de l'aubier, surface des anneaux de croissance, densité du bois, cime des arbres, LiDAR

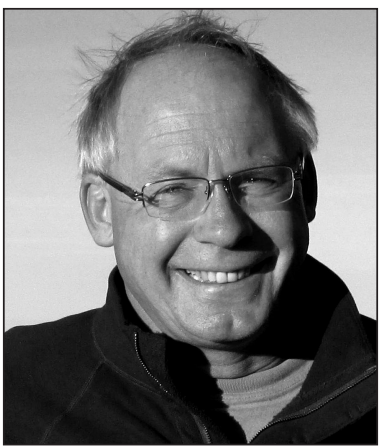

Arthur Groot

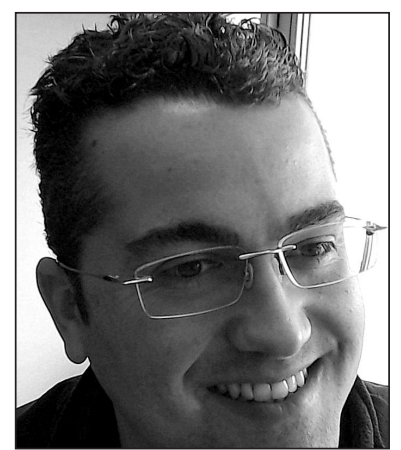

Francesco Cortini

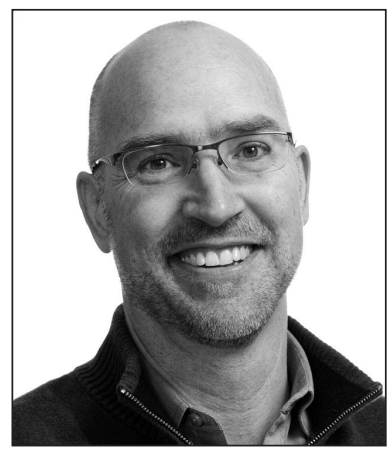

Michael A. Wulder

\footnotetext{
${ }^{1}$ Natural Resources Canada, Canadian Wood Fibre Centre, 1219 Sault Ste. Marie, Ontario P6A 2E5 *corresponding author art.groot@gmail.com

${ }^{2}$ Natural Resources Canada, Canadian Wood Fibre Centre, 506 West Burnside Rd., Victoria, British Columbia V8Z 1M5
} 


\section{Introduction}

The value of timber for manufactured wood products may be affected by a number of tree and wood characteristics (or wood fibre attributes). Wood fibre attributes are those characteristics of trees and wood which influence the physical, mechanical and chemical properties of forest products derived from wood (Canadian Wood Fibre Centre 2010). Trees and wood can be characterized in many ways including: appearance attributes, permeability, moisture content, energy content, wood density, cell dimensions, microfibril angle, chemical composition, decay resistance, knot size and distribution, wood grain geometry, wood strength properties (e.g., modulus of elasticity), tree taper and tree diameter (Panshin and de Zeuw 1970, Canadian Wood Fibre Centre 2010). Better information about selected fibre attributes can support improved decisions about timber management planning and operations and can help to diversify and add value to products manufactured by the Canadian forest sector (MacKenzie and Bruemmer 2009).

Forest resource inventories are a suitable platform for information about fibre attributes, but current Canadian forest inventories generally include little information related to the value of timber. Current inventory attributes such as height, species composition and stocking can be used to estimate volume by species but provide no further information about other attributes that influence the value of the timber. Current forest inventories are based chiefly on interpretation of aerial photography with field plots used for calibration (Pitt and Pineau 2009). The cost of field plots and associated laboratory analyses rules out ground sampling as the primary approach for enhancing forest inventories with fibre attributes. Instead, approaches based on remote sensing are needed to add fibre attributes to forest inventories (van Leeuween et al. 2011). For instance, an approach based on individual tree crowns is an attractive possibility because remote sensing technologies obtain information about the forest canopy and because the tree crown is influential in wood formation (Larson 1969). Advances in remote sensing technologies are making it feasible to estimate some features of individual trees using automated approaches (Wulder et al. 2004). Tree height can be estimated from LiDAR densities as low as 1 return per $\mathrm{m}^{2}$, but estimation of features such as crown diameter requires higher densities or combined analysis with digital imagery (Leckie et al. 2003, Coops et al. 2004, Wulder et al. 2008).

It has long been argued that tree crown has a determining role on wood quality, since wood quality is the result of the biological process of wood formation, which in turn is regulated by physiological processes originating in the foliage (Larson 1969). For a number of fibre attributes, however, there has been surprisingly little investigation of the relationship between crown features and wood quality. Amarasekara and Denne (2002) found that ring width strongly increased with foliar mass in Pinus nigra, but wood density and modulus of elasticity were poorly related to foliar mass. In Pinus sylvestris grown under different silvicultural regimes, the distance to the green crown and proportion of green crown were significant predictors in models for a number of fibre attrib- utes (Eriksson et al. 2006). In Pinus contorta, the transition from juvenile to mature wood, as indicated by patterns of wood density, was related to crown length, position relative to the crown base and tree age (Mansfield et al. 2007). In Pinus resinosa, the fit of models of breast height individual ring wood density as a function of crown dimension improved with age (Larocque and Marshall 1995).

In 2009, the Canadian Wood Fibre Centre (CWFC) initiated a project termed Crown-Fibre Attribute Relationships (CFAR). The objective of this project was to explore the potential relationships between tree crown characteristics and fibre attributes and their application to remotely sensed crown features in order to provide estimates of fibre attributes for enhanced forest inventories. The CFAR project used a number of data sets, often from silvicultural experiments, that had created a range of crown conditions following spacing and thinning treatments. The CFAR project completed analyses of the influence of a number of crown characteristics on several fibre attributes (Table 1). The objective of this article is to summarize the progress of the CFAR project in the context of other relevant research, and to identify the prospects for further work in this area.

\section{A Framework for Classifying Fibre Attributes at Tree Level Resolution}

The geometry of a tree is a useful organizing framework for classifying and discussing fibre attributes. Fibre attributes are inherently zero-, one-, two- or three-dimensional with respect to the geometry of the tree stem in cylindrical coordinates (Table 2, Fig. 1). Zero-dimensional attributes, such as stem circumference at breast height, are represented by a single value for a tree. One-dimensional attributes, such as stem circumference or sapwood area, vary along the longitudinal axis of the stem, and are represented by a single value at a given point along the stem. Two-dimensional attributes, such as stem diameter or sapwood width, vary both along the longitudinal axis and with either radial direction around the circumference of the stem or with radial distance (distance from the pith to the bark). Finally, three-dimensional attributes, such as wood density, vary longitudinally and with both radial direction and distance.

The dimensionality of some fibre attributes can be reduced to provide a reference or partial value of the attribute. For example, stem circumference is inherently one-

Table 1. Summary of publications from the Crown-fibre attribute relationships (CFAR) project.

\begin{tabular}{|c|c|}
\hline Fibre Attribute & Publications \\
\hline Diameter at breast height & $\begin{array}{l}\text { Cortini et al. (2011), } \\
\text { Filipescu et al. (2012) }\end{array}$ \\
\hline Maximum branch diameter & Groot and Schneider (2011) \\
\hline Sapwood area distribution (longitudinal) & Cruickshank et al. (in review) \\
\hline Ring area distribution (longitudinal) & Cortini et al. (2013) \\
\hline $\begin{array}{l}\text { Wood density, microfibril angle, } \\
\text { modulus of elasticity (radial) }\end{array}$ & Cortini et al. (2014) \\
\hline Wood density (longitudinal) & Groot and Cortini (in review) \\
\hline
\end{tabular}


Table 2. Inherent dimensionality of fibre attributes

\begin{tabular}{|c|c|c|}
\hline Dimensionality & Source of Variation & Fibre Attributes \\
\hline 0 & Tree & $\begin{array}{l}\text { Tree circumference at breast height, tree slenderness, maximum knot } \\
\text { diameter, knot size frequency distribution }\end{array}$ \\
\hline 1 & Longitudinal & $\begin{array}{l}\text { Stem circumference, sapwood area, area of juvenile wood, area of outer ring, } \\
\text { number of knots per stem unit, maximum knot diameter per stem unit }\end{array}$ \\
\hline $2 \mathrm{a}$ & Longitudinal + Azimuthal & Stem diameter, sapwood width, width of outer growth ring \\
\hline $2 b$ & Longitudinal + Radial & Ring area \\
\hline 3 & Longitudinal + Azimuthal + Radial & $\begin{array}{l}\text { Ring width, wood density, fibre length, cell wall thickness, cell diameter, } \\
\text { microfibril angle, modulus of elasticity, knot presence, knot diameter }\end{array}$ \\
\hline
\end{tabular}

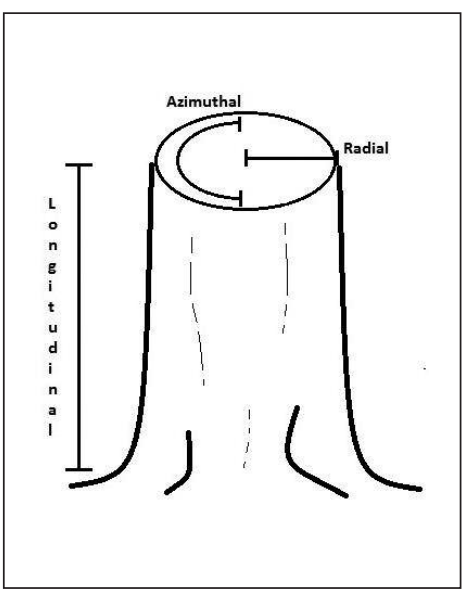

Fig. 1. Dimensionality of fibre attributes.

dimensional (varies along the longitudinal axis), but circumference at breast height (usually further translated to $\mathrm{DBH}$ ) is a widely-used zerodimensional reference value. Attribute variation in three dimensions is ignored when dimensionality is reduced by restricting measurements to only part of the tree. For example, measurements of wood density at the breast height part of the stem do not take into account any vertical dependence of this property and may provide a poor indication of wood density over the entire tree (Repola 2006).

The dimensionality of fibre attributes with dimensionality greater than zero can also be reduced by averaging. For example, a tree-level average of wood density reduces the dimensionality of this attribute from three to zero. Reduction in dimensionality by averaging is necessary for practical application of fibre attribute information in forest operations and management, but it should be noted that averaging reduces information about the attribute. Patterns of variation for some fibre attributes may be quite pronounced, such as the radial decline in wood density and microfibril angle with distance from the pith (Cortini et al. 2014), and averaging obscures these patterns. Averages of fibre attributes should be weighted by volume to properly represent the bulk characteristics of wood.

Because fibre attributes often change with age, combining both partial measurement and averaging can provide a common basis for comparison. For example, Pohkarel et al. (2014) used the average wood density and latewood percentage of the first 50 growth rings at breast height part of the stem to develop models with a common reference age. It is also important to take into account differences in dimensionality when comparing results of different studies. For example, isolating the effect of position along the stem on wood density using disk averages is problematic because the average disk density is influenced both by the steadily changing radial ring pattern and by any genuine height effect (Gjerdrum and Eikenes 2014).

\section{Zero-dimensional fibre attributes}

Zero-dimensional fibre attributes are represented by a single value per tree, and are often an expression of allometry (e.g., tree slenderness or tree height/DBH). The strong allometry between tree height and DBH (Watt and Kirschbaum 2011) and between branch length and diameter (Bertram 1989) is likely a result of biophysical constraints (particularly mechanical and hydraulic) on tree form and function.

\section{$\mathrm{DBH}$}

$\mathrm{DBH}$ is more typically thought of as a tree attribute than a fibre attribute, but it is included here because it is a main determinant of not only tree volume, but also of net monetary value. The value per unit volume generally increases with tree size because other value attributes (e.g., smaller proportion of corewood, proportion of clearwood, appearance) generally improve with tree size, and because a greater range of products (e.g., larger dimension lumber) can be manufactured from larger trees. The cost per unit volume of harvest, transport and milling generally decreases with increasing tree size as well (Holtzscher and Landford 1997).

\section{Progress in predicting DBH from characteristics}

Simple linear or log-log relationships have been used previously to predict DBH from remotely sensed height and crown area or crown diameter for individual tree species or locations (e.g., Zagalikis et al. 2005, Popescu 2007, Brandeis et al. 2009). The CFAR project demonstrated that DBH for a number of Canadian species can be estimated from tree height, crown characteristics, and stand and site attributes using non-linear equations with a typical RMSE of about 10\%-15\% (Cortini et al. 2011, Filipescu et al. 2012, Fig. 2). Subsequent research in other jurisdictions has also used non-linear DBH-height relationships (Bi et al. 2012), and included crown variables such as crown diameter in models (Gonzalez-Benecke et al. 2014, Balenovic et al. 2015).

The size of the tree crown is strongly influenced by stand development and silvicultural treatment history, so the inclusion of crown characteristics in $\mathrm{DBH}$ prediction models accounts for much, but not all, of the effect of history and treatment (Filipescu et al. 2012). The same size of tree crown 


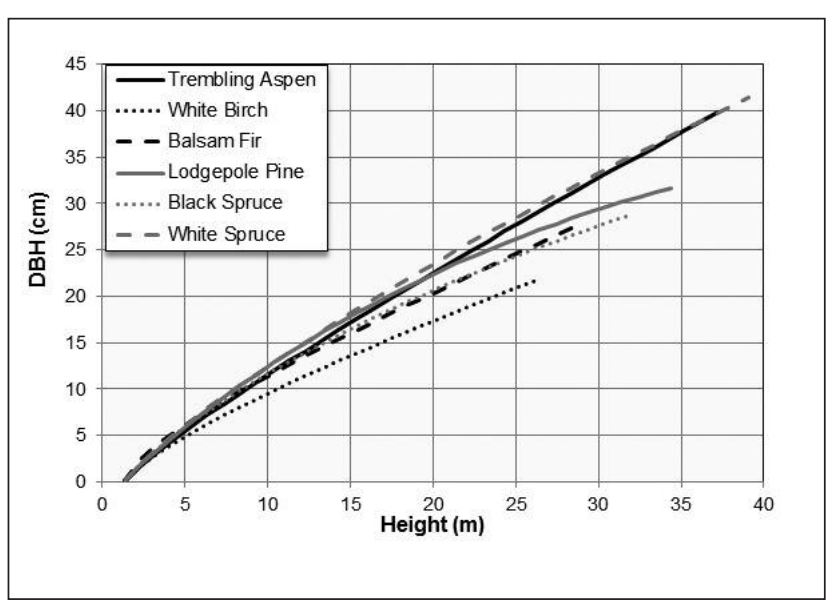

Fig. 2. $\mathrm{DBH}$ predicted from tree height and crown characteristics for six tree species in Alberta from models developed by Cortini et al. (2011).

can be the result of different stand developmental pathways having different cumulative effects on tree diameter. Different treatments (or more generally stand histories) can result in differing, but eventually convergent trajectories of crown characteristics. Consequently, the relationship between crown size and $\mathrm{DBH}$ is not unique, and the inclusion of treatment or history in models can improve the accuracy of estimates.

\section{Prospects for improving prediction of $\mathrm{DBH}$ and related attributes from crown characteristics}

The prediction of $\mathrm{DBH}$ from crown features has attracted more research than other fibre attributes, and the prediction approaches are reasonably mature. The feasibility of predicting DBH leads to the possibility of also predicting a related attribute, stem taper. Both the quantity (product recovery) and quality of forest products (e.g., lumber grain angle) processed from tree boles are directly influenced by the taper of the tree stem. Stem taper is also correlated with a number of other fibre attributes (e.g., juvenile wood content, knot size and distribution) because it integrates the cumulative history of the tree's crown (Larson 1963, Jozsa and Middleton 1994). Stem taper may also have a mechanistic influence on the strength properties of the tree stem (Groot and Cortini in review), a possibility discussed in more detail in the section on wood density in this article.

Tree slenderness is a zero-dimensional expression of stem taper, a valuable integrating tree attribute. More slender trees typically have fewer large knots, less juvenile wood content and lower slope of grain (Canadian Wood Fibre Centre 2010). Slenderness can be computed from height estimated via remote sensing, divided by DBH estimated from the models described above. A future prospect is to construct models to estimate slenderness directly from remotely sensed variables, potentially reducing the error associated with model estimates of DBH. The elimination of DBH from the slenderness expression by substituting an increasing function of tree height and crown dimensions (e.g., Filipescu et al. 2012) would lead to a model form that is primarily an inverse relationship between slenderness and crown dimensions.

\section{Maximum branch diameter}

The value of sawn wood is strongly affected by knots which influence both the strength and appearance of lumber. Knots arise from tree branches, and the maximum branch diameter (MBD) is an indicator of the maximum knot size within and below the tree crown (Groot and Schneider 2011).

\section{Progress in predicting MBD from crown characteristics}

Not surprisingly, there is a strong allometric relationship between branch diameter and length (Bertram 1989); longer branches are thicker. Correspondingly, the CFAR project found that MBD was strongly related to crown radius for a number of species (Groot and Schneider 2011), a result previously obtained by Garber and Maguire (2005). MBD also increased with height and decreased with stand basal area and basal area of larger trees, likely because of the effects of wind loading and competition on branch architecture (Groot and Schneider 2011, Fig. 3). Typical RMSE for the CFAR MBD models was about $3 \mathrm{~mm}$ or roughly $10 \%$ of measured values, similar to the relative accuracy of the CFAR DBH models. In contrast to the result for $\mathrm{DBH}, \mathrm{MBD}$ prediction error was not related to silvicultural treatment.

\section{Prospects for predicting related branch and knot attributes from crown characteristics}

MBD can serve as a key input or constraint into models that predict distributions of branch diameters along the stem (e.g., Garber and Maguire 2005). Although not examined in the CFAR project, it seems likely that the distribution of branch diameter along the stem will be strongly related to the distribution of crown radius along the stem. Consequently, remote sensing methods that provide information on crown profiles could provide a basis for the estimation of branch diameter distribution.

An additional variable that could potentially be used to constrain branch diameter distributions is the cumulative sum of branch basal areas. The observation by Leonardo da Vinci that "all branches of a tree at every stage of its height when put together are equal in thickness to the trunk" (Richter 1888) has been interpreted as a feature of the tree's water transport system (Hari et al. 1986), or as response to wind-induced stresses (Eloy 2011). In any case, there is a very strong relationship between the cross-sectional area of the tree stem at a point and the sum of the cross-sectional area of branches above that point (Hari et al. 1986, Bentley et al. 2013). A cumulative branch area constraint would ensure realistic branch amounts at the tree level, although climatic variation in the branchwood area to stemwood area ratio must be taken into account (Berninger et al. 1995).

The translation of branch diameter information to estimates of knot size and frequency is necessary to complete the linkage to net monetary value. Recently, Duchateau et al. (2013) developed models to estimate knot shape and diameter using branch diameter and stem radius. Coupled with existing knowledge and models to estimate branch diameter, these knot models point to encouraging prospects for deriving knot information from crown observations.

\section{One-dimensional fibre attributes}

One-dimensional fibre attributes, such as stem circumference and sapwood area, vary along the length of the stem. One- 

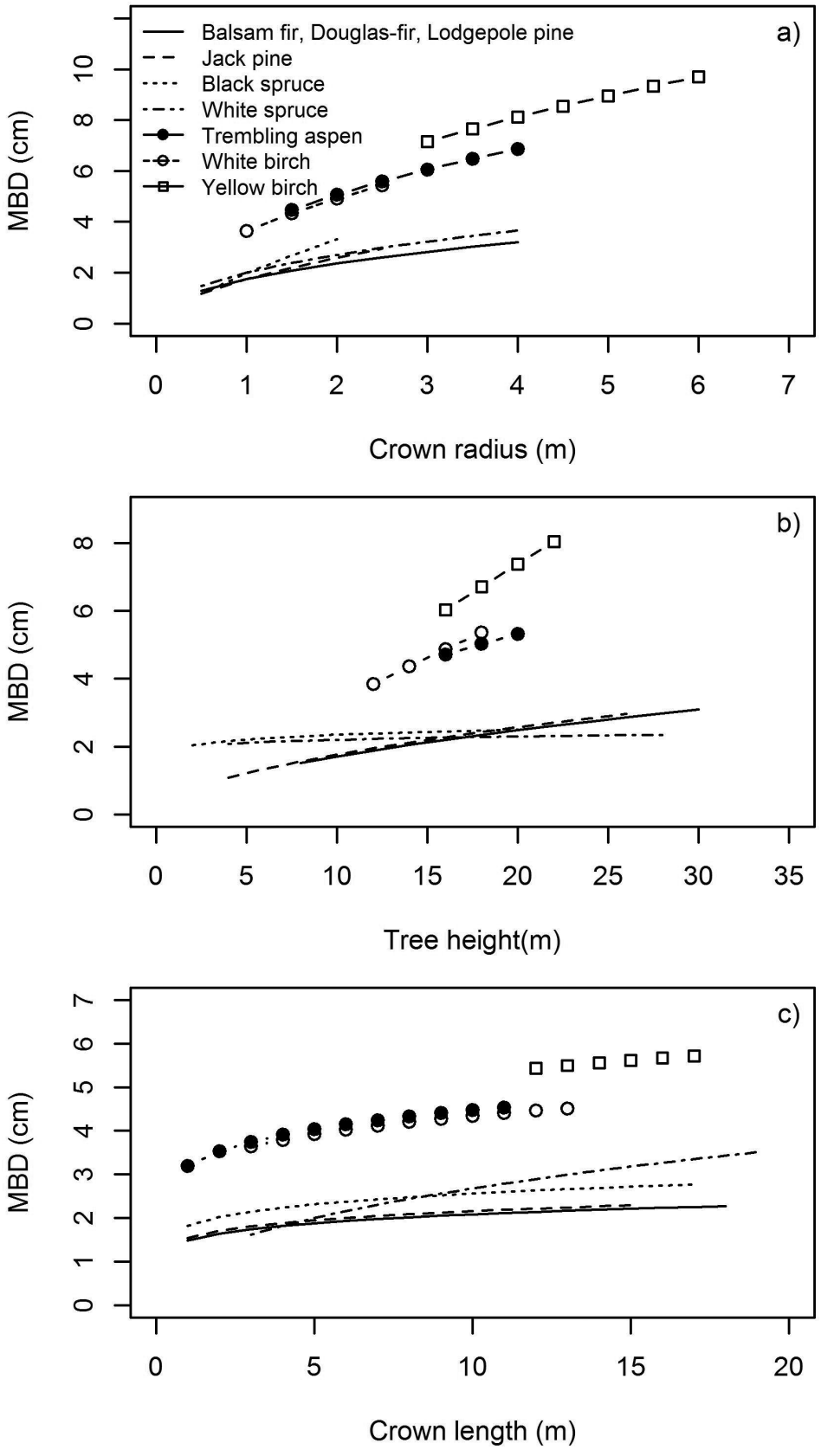

Fig. 3. Mean diameter of the three largest branches (MBD) versus crown radius, tree height and crown length predicted from crown characteristics models for seven Canadian tree species (Groot and Schneider 2011).

dimensional attributes are often a generalization of twodimensional attributes that vary with direction around the circumference. For example, stem circumference is a generalization of stem diameter, which varies with direction. This generalization is usually based on the assumption that the stem is circular in cross-section, which is never exactly true but commonly used for practical purposes. In another example, sapwood area is the generalization of heartwood and sapwood thicknesses.

\section{Sapwood area}

Sapwood is the outermost region of the stem xylem and conducts water and nutrients from the roots to the foliage. Sapwood is eventually transformed into heartwood, although the process is not well understood (Taylor et al. 2002). Sapwood and heartwood have different appearances, moisture, and chemical characteristics which influence their value as forest products. In general, forest products that consist only of sapwood or only of heartwood are less variable than products consisting of both types of wood.

\section{Progress in predicting sapwood area from crown characteristics}

Sapwood cross-sectional area of the stem at the base of the live crown is widely used to predict foliage mass, consistent with the pipe model theory (Waring et al. 1982, Dean and Long 1986). In the CFAR project, the distribution of sapwood area along stems of lodgepole pine (Pinus contorta Dougl. ex Loud) and western hemlock (Tsuga heterophylla (Raf.) Sarg.) was modelled using a functional approach based on the pipe model theory and an empirical approach based on stem taper models (Cruickshank et al. in review). Explanatory variables included tree height, crown dimensions, position of the crown base and distance along the stem from the tree apex. Both models predicted sapwood area with low bias (RMSE $<10 \%)$ over most of the stem (Fig. 4).

Prospects for predicting combined sapwood and heartwood areas from crown characteristics

The CFAR work successfully modelled the distribution of sapwood, but these models need to be linked to either heartwood area or to stem taper to fully describe the location of sapwood within trees. A potential approach is to simply apply existing taper models, but in this case the error in sapwood location combines the errors of two independently fitted models. A preferable approach is to jointly fit models that involve two of the following variables: sapwood area, heartwood area, stem taper, sapwood area fraction.

\section{Two-dimensional fibre attributes}

The second dimension for two-dimensional fibre attributes can be either direction around the circumference (dimensionality $2 \mathrm{a}$; Table 2) or position from pith to the bark (dimensionality $2 \mathrm{~b}$; Table 2 ). For fibre attributes of dimensionality $2 \mathrm{a}$, the variation of fibre attributes with direction around the circumference represents non-systematic anisotropy. Variation along the longitudinal axis is usually of 
FC model
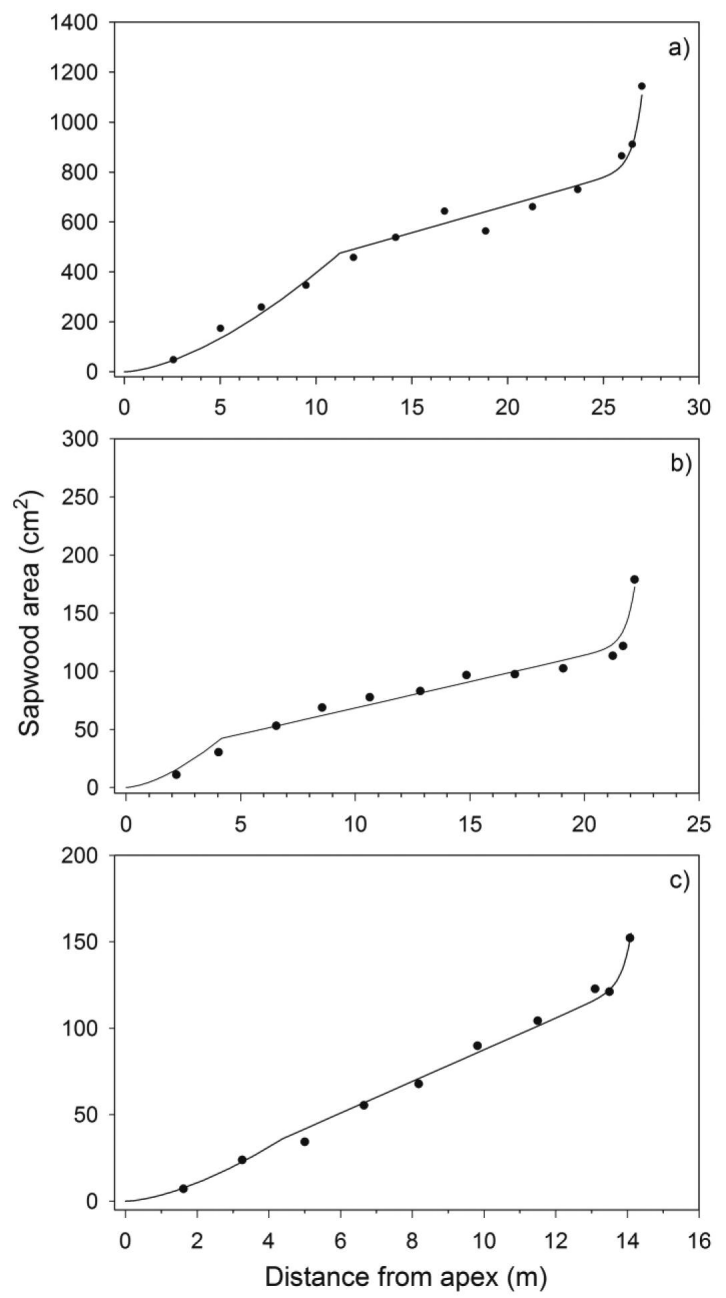

GF model
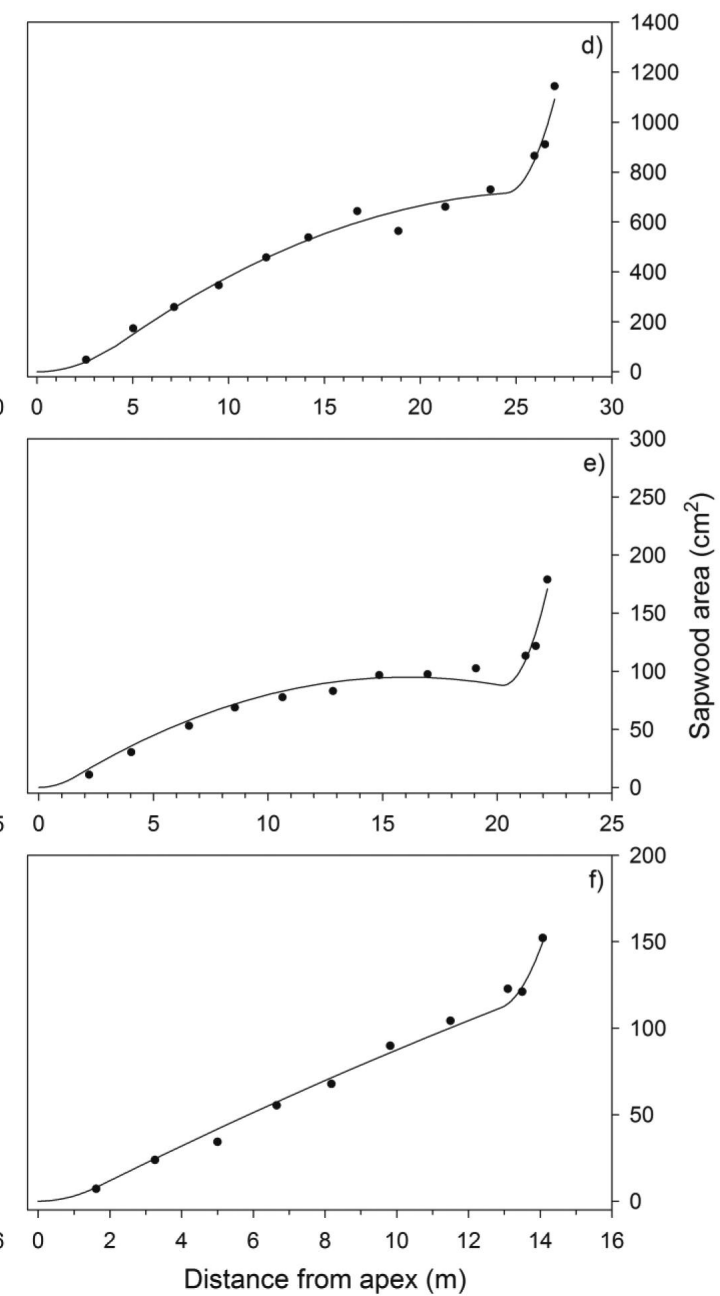

Fig. 4. Predicted (lines) and observed (solid circles) sapwood area for three lodgepole pines from mixed effects models developed by Cruickshank et al. (in review). The FC model $(\mathbf{a}, \mathbf{b}, \mathbf{c}$ ) is a functional components model based on pipe model theory and the GF model $(\mathbf{d}, \mathbf{e}, \mathbf{f})$ is a segmented polynomial model originally applied to stem taper. The FC and GF models include tree-level random effects and fixed effects crown variables.

much greater interest and the variation with radial direction is simply averaged (stem diameter is a good example). In contrast, for fibre attributes of dimensionality $2 \mathrm{~b}$ such as ring area, both dimensions are of interest. These attributes vary systematically both along the longitudinal axis and with distance from the pith. The spatial position of these fibre attributes is directly linked to the time of wood formation, introducing the complexity of a temporal aspect to model construction.

\section{Ring area}

The width of the annual growth ring is considered an indicator of wood quality (Panshin and de Zeuw 1970), with narrow rings generally being more desirable. Greater latewood proportion and higher wood density are to a greater or lesser degree (see section on wood density below) associated with narrower rings. Additionally, the cumulative result of ring width through a tree's history, stem taper, is a key determinant of wood quality (Jozsa and Middleton 1994). Ring width is a three-dimensional fibre attribute that shows considerable variation in the radial and longitudinal directions (Farrar 1961). Average annual ring width is geometrically related to annual ring area, a two-dimensional fibre attribute that can be integrated with respect to the longitudinal axis of the tree to obtain annual wood volume increment. Since the volume increment of individual trees is strongly related to the size of the tree crown (Mitchell 1975, Gilmore and Seymour 1996, Ottorini et al. 1996), it follows that the magnitude of ring area is likely related to tree crown dimensions. Furthermore, the distribution of ring area along the stem frequently follows a characteristic pattern known as Pressler's law: "Ring area growth (crosssectional area of a single annual increment) at any one point on the stem is proportional to the quantity of foliage above this point" (Pressler 1864 as cited by Larson 1963). 
Progress in predicting ring area distribution from crown characteristics

The CFAR project developed models to describe the distribution of ring area increment of the outer rings for four Canadian conifers based tree crown dimensions, location of the crown base, tree competitive status, and site quality (Cortini et al. 2013). Ring area increased from the stem apex to the effective crown base (63\% of the crown length from the apex). Ring area was then more or less constant until a region of pronounced butt flare near the base of the tree. These models explained much of the variation in ring area increment with RMSE of about $15 \%$ of mean values (Fig. 5).

\section{Prospects for improving predictions of ring area from crown characteristics}

The models developed by Cortini et al. (2013) show that there is considerable potential to estimate the current ring area distribution and volume increment from simple crown variables. For models to be broadly applied however, it will be necessary to incorporate site quality and climate effects. Groot and Saucier (2008) showed that crowns on lower quality sites produce less stem volume increment per unit of light intercepted. Thus, site index may be suitable for representing the effect of site quality on ring area (Cortini et al. 2013). The CFAR ring area models use current crown information to describe only the outer rings of a stem, providing a highly incomplete understanding of a tree's fibre attributes. The temporal challenge is discussed later in this paper.

\section{Three-dimensional fibre attributes}

Although a number of fibre attributes vary in three dimensions (Table 2), the dimensionality is almost always reduced by averaging or subsampling. The high cost of sampling is one reason for the reduction of dimensionality but another reason is that there is much greater practical interest in patterns of variation from pith to bark and along the longitudinal axis than in patterns of variation with direction around the stem circumference.

Three-dimensional fibre attributes are the most complex, not just from a spatial point of view but also because the temporal aspect becomes inescapable. The radial variation in attributes is a reflection of wood formed at different times during the life of a tree. A temporal problem arises in development of relationships between crown characteristics and fibre attributes: the characteristics of the past crown when wood was formed near the pith at the base of the tree may bear little resemblance to the characteristics of the current crown. An initial solution to the temporal problem is to examine relationships between current crown characteristics and current timber value attributes averaged across radial directions (i.e., average attributes in the outer wood or last few rings). This approach reduces the problem to one dimension, but also ignores the older wood in the tree. If relationships exist between the current crown and timber attributes, then approaches to estimate past (closer to the pith) attributes must be developed. Possible approaches to this temporal problem are discussed later in this paper.

\section{Wood density}

The CFAR project focused on wood density as a pilot for three-dimensional attributes because: (i) it is an important fibre attribute; (ii) previous work suggested that the tree crown could be an influencing factor; and, (iii) it is related to other three-dimensional fibre attributes (e.g., Blanchette et al. 2015). Wood density is a key fibre attribute because it is a major influence on a number of processing and end-product characteristics of lumber, and pulp and paper products (Wegner et al. 2010). Higher strength of lumber, pulp and paper is associated with higher density, as is higher throughput of pulp. Uniformity of wood density is also important as it contributes to the efficiency of processing and the uniformity of end-products.

Density varies substantially in the radial direction within rings of Canadian conifers, and distinct transitions between lower density earlywood and higher density latewood are usually apparent (Zhang and Koubaa 2008). Because the proportion of earlywood changes in wider rings (Larson 1969), foresters and wood scientists have long concluded that lower wood density is a result of more rapid growth rates (Saranpää 2003). The evidence for an association between density and growth rate is mixed, however. Although some high correlations have been reported (Lindström 1996b, 1996c), correlations are often weak or moderate (Zhu et al. 2007, Jyske et al. 2008) and may vary with age, location in the tree and with the environment (Larocque and Marshall 1995, Dutilleul et al. 1998, Downes et al. 2002).

The regulatory role of physiological processes in the crown on wood formation (Larson 1969) led Lindström (1996a) to conclude that "models accurately predicting basic density should be based on a set of variables closely related to crown development". Larocque and Marshall (1995) found that wood density in Pinus resinosa Ait. generally decreased with crown width, volume and ratio in an age-dependent manner. In some studies, wood density of annual rings increased with distance along the stem below the crown (Gartner et al. 2002, Jyske et al. 2008, Vincent et al 2011), but other investigations found no effect of location along the stem (Mäkinen et al. 2007). In general, limited progress has been made on the development of wood density models that incorporate crown-related variables.

Any progress in the development of relationships for wood density may be applicable to related three-dimensional fibre attributes. Wood density is directly proportional to the cell wall fraction and increases with increasing cell wall thickness and decreasing lumen content of tracheids (Saranpää 2003). Wood density and microfibril angle together determine the modulus of elasticity (Evans 2006).

Progress in predicting wood density from crown characteristics To best detect crown influences on wood density, CFAR analyses were carried out using data from silvicultural experiments that created a wide range of crown sizes (Cortini et al. 2014; Groot and Cortini in review). Two-dimensional ring resolution (pith to bark and along the stem) wood density for balsam fir (Abies balsamea L. Mill.) was most strongly related to distance from the pith, declined weakly with ring width, and was unrelated to position along the stem (Cortini et al. 2014). Wood density in the outer rings along the stems of balsam fir and white spruce (Picea glauca Moench Voss) was related to measures of stem slenderness, relative tree height and ring width (Groot and Cortini in review). The CFAR results are consistent with an emerging interpretation that 

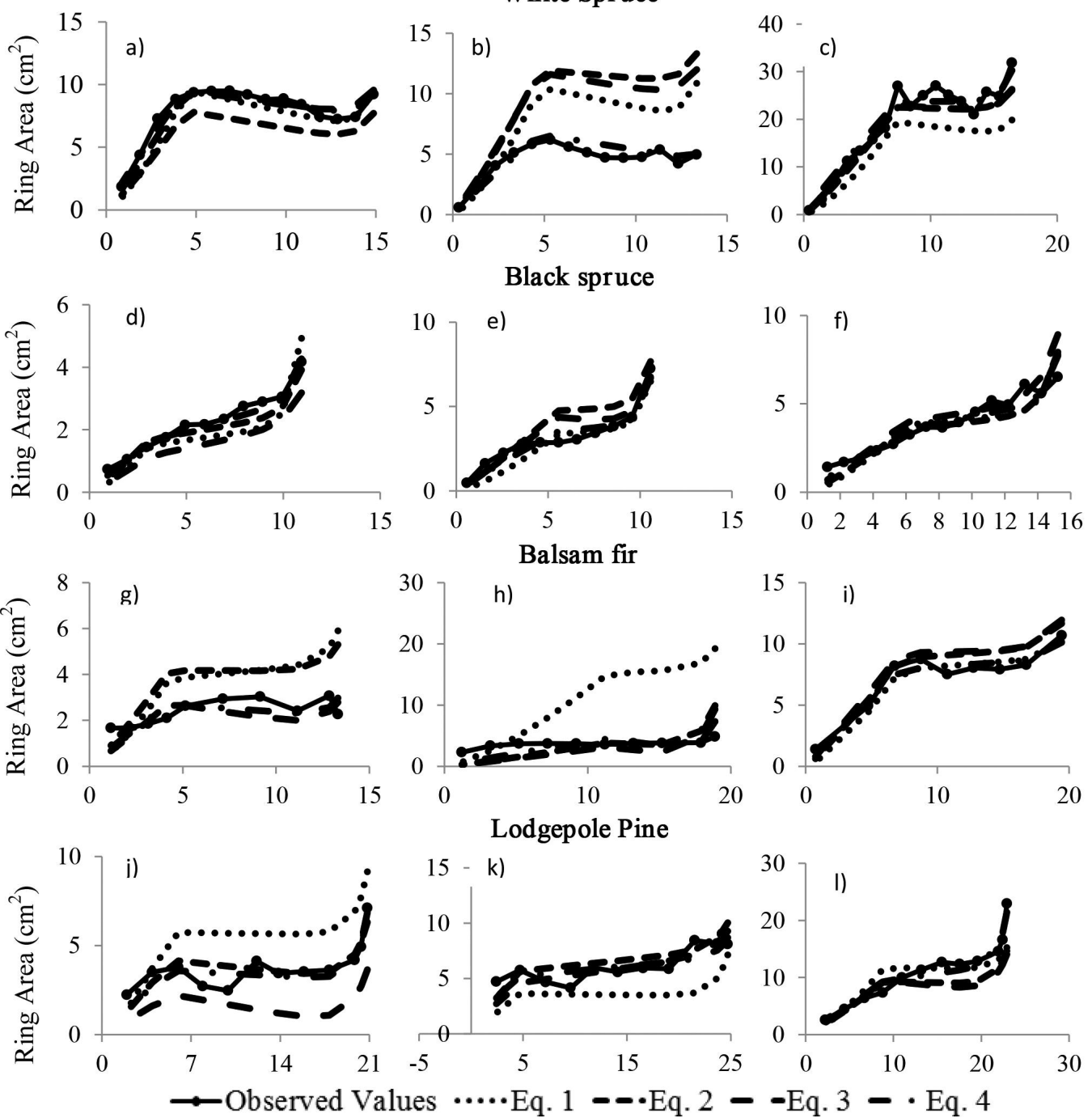

Distance from the Apex (m)

Distance from the Apex (m)

Distance from the Apex (m)

Fig. 5. Predictions of ring area distribution along the tree stem for trees representing the $25^{\text {th }}(\mathbf{a}, \mathbf{d}, \mathbf{g}, \mathbf{j}), 50^{\text {th }}(\mathbf{b}, \mathbf{e}, \mathbf{h}, \mathbf{k})$ and $75^{\text {th }}(\mathbf{c}, \mathbf{f}, \mathbf{i}, \mathbf{l})$ percentiles of annual volume increment within species from models developed by Cortini et al. (2013). Equation 1 is a fixed effects model without crown variables; Equation 2 a fixed effects model with crown variables; Equation 3 a fixed effects model with crown and competition status variables; and, Equation 4 a mixed effects model with tree-level random effects as well as crown and competition variables.

ring width is not a causal factor in wood density, although it may be correlated (Mason 2008). In this interpretation, patterns of wood density are a response to a tree's requirement to maintain mechanical integrity and hydraulic function. Greater wood density confers greater mechanical strength and allows trees to resist bending and twisting (Niklas and Spatz 2010). Cells with smaller lumens and thicker cell walls provide greater resistance to xylem conduit embolism during water stress (Hacke et al. 2001), at the cost of reduced water transport efficiency (Domec and Gartner 2002).

The hypothesis that the stem's biomechanical require- ments influence wood density is supported by the widely observed relationship of stem slenderness to wood density (Lindström 1996b, Groot and Cortini in review) and to wood stiffness (Lei et al. 2005, Roth et al. 2007, Warren et al. 2009, Kijidani et al. 2010, Lowell et al. 2014). Although stems of low slenderness (high taper) and wide rings are both associated with large crowns, the inconsistent influence of ring width on wood density suggests that association between slenderness and wood density may not be simply correlative. The lower wood density sometimes observed in trees of lower social position (Kärkkäinen 1984, Groot and Cortini in review) also 
supports the biomechanical hypothesis, since trees less exposed to wind require less stiffness. Not all species show greater wood density for canopy versus sub-canopy trees however, possibly because the larger diameter of canopy trees confers greater strength, so reducing the need for reinforcement by higher wood density (Woodcock and Shier 2002, 2003).

Cortini et al. (2014) noted that wood density in Abies balsamea was affected by weather, with wood density for individual years increasing with the number of growing degree days in that year (Fig. 6). This is consistent with the results of Franceschini et al. (2013) who observed increasing maximum ring density with warmer summers in Picea abies. More broadly, wood density is also influenced by site quality and climate (Mäkinen et al. 2007, Pokharel et al. 2014), which may be a manifestation of the effects of site water balance on stem hydraulic function.

\section{Prospects for better prediction of wood density and related fibre attributes from crown characteristics}

Since ring width may not have a causal influence on wood density, it is not surprising that the strong relationship of crown variables with ring area (and consequently ring width) is not apparent for wood density. A further implication is that models using ring width to predict wood density may be unreliable (Mason 2008). A better understanding of functional ecology of wood formation is needed as a foundation for more reliable wood density models.

As noted previously, the temporal aspect of variation becomes prominent for three-dimensional fibre attributes, including wood density. In the context of forest inventory, remote sensing provides only the current crown characteristics, whereas estimates of wood fibre attributes representing the entire life of the tree are required. Current crown characteristics influence fibre attributes only in the last rings near the bark, while rings closer to the pith progressively reflect crown characteristics further into the past. The severity of the temporal problem varies among fibre attributes and generally appears to increase with the inherent dimensionality of the attribute. In the CFAR project, the temporal problem was minor or not detected for models to estimate $\mathrm{DBH}$, maximum branch diameter and sapwood area distribution. The temporal problem becomes more acute for fibre attributes that vary with the radial distance dimension (e.g., ring area, wood density).

Little work has been done on resolving this temporal problem with respect to the dynamics of crown characteristics, but several approaches seem possible. One approach is to model the past trajectory of crown conditions and use these to predict fibre attributes. Another approach is to estimate fibre attributes in the last rings using current crown characteristics, and then constrain models of radial profiles of fibre attributes to pass through this point. This approach could take advantage of the considerable information on typical radial profiles that is embedded in existing observations and models of radial fibre attributes (e.g., Lachenbruch et al. 2011). It has also been pointed out that the longitudinal pattern of fibre properties within an annual ring approximates the radial pattern across successive annual rings (Lachenbruch et al. 2011). This similarity may allow longitudinal models of fibre properties in the last few rings to serve as a template for radial models.

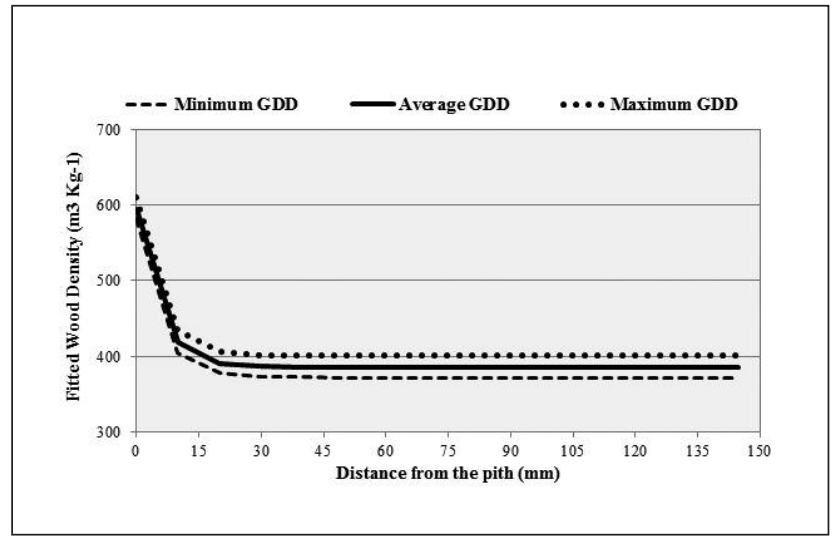

Fig.6. Predicted wood density in balsam fir using models developed by Cortini et al. (2014) for minimum average and maximum annual values of growing degree days (GDD) for the study location.

\section{Remote sensing of crown characteristics Progress in remote sensing of crown characteristics}

Remote sensing provides a unique opportunity for capturing and describing tree crowns. The downward-looking view allows crowns to be viewed with less obstruction than from below and for digital analysis techniques to be applied. Imagery from a number of different sources of sensors and data types has been deployed to detect and delineate tree crowns, including photography, multi- and hyperspectral digital imagery, as well as LiDAR. Reviews of approaches for using high spatial resolution data at the tree level and more directly on tree crown characterization can be found in Culvenor (2003), Ke and Quackenbush (2011), and Hyyppä et al. (2012).

Regardless of the method applied and the type of data used, there are fundamental limitations to what can be captured as a function of the relationship between the image spatial resolution and the size of the tree crowns (Wulder et al. 2004). Multiple pixels need to represent each crown to provide a given algorithm with the necessary information to distinguish crown from non-crown vegetation and from other crowns. Too low a spatial resolution will result in an inability to isolate and delineate a given crown, thus providing an unstable representation of crowns and crown area. A further complication is the layering of crowns in more complex multi-aged stands (Duncanson et al. 2014). The overlapping of crowns is a persistent issue, often resulting in the representation of tree clusters necessitating a need for rule-based breaking of the clusters (Duncanson et al. 2014). It is also worth noting that too high a spatial resolution may result in larger crowns being divided up into multiple crowns (Ke and Quackenbush 2007). Crowns that result from the analysis of remotely sensed data are a function of the data type and analysis methods applied (Ke and Quackenbush 2011). Most research to date has been undertaken on panchromatic data, with outstanding opportunities for additional multispectral information to be exploited in crown delineation algorithms, especially for initial separation of crown from background vegetation. Looking forward as the detection capabilities of various algorithms and the preferred conditions for application are increasingly known, there are 
opportunities for combining multiple detection algorithms to avail more upon the spectral information content present and to tune a given algorithm based upon the density and characteristics of the crowns (e.g., shape, size). Vastaranta et al. (2011) indicate that errors in initial tree detection prior to, or in support of, tree crown delineation have the greatest impact upon resultant attributes generated and forest management planning applications.

Passive optical imaging data provides for a full representation of spatial features in comparison to LiDAR where point data is converted to a surface (Axelsson 1999). As a result, capabilities to identify tree crowns and the methods used vary greatly according to the type of data used (Coops et al. 2004). While LiDAR may not be initially collected as a continuous surface in the same manner as optical data, the height information generated can be used to assist in dividing larger objects into multiple crowns or differentiating between strata. The recommendation, following Coops et al. (2004), for users with access to both high spatial resolution imagery and LiDAR data, is to use the imagery to delineate tree crowns and use the LiDAR height information to add additional information to the crowns or to offer additional discriminating power to the algorithms applied. LiDAR can be used to separate ground vegetation from trees as well as to offer additional information for the breaking up of clusters into individual tree crowns. In general, tree crown identification algorithm performance is better for more uniform stands (e.g., even-aged, evenly spaced).

Airborne remote sensing enables the collection of data that has high spatial resolution and that includes a number of different spectral channels. Spectral information can be valuable in the delineation of tree crowns (Pouliot et al. 2002) by offering improved tree top identification and crown edge delineation. Space borne systems can have similar spatial resolutions to some airborne systems, but typically only for a panchromatic channel (sub-metre; Belward and Skøien 2014). In contrast, airborne systems are capable of subdecimeter spatial resolutions over a number of wavelengths (Wulder et al. 2004).

\section{Prospects for improving remote sensing of crown character- istics}

It is expected that the combined use of LiDAR and optical image data will continue and expand (Hyyppä et al. 2012, Wulder et al. 2013). LiDAR can be used independently in the characterization of tree crowns (Chen et al. 2006), but for greater benefit should be used in conjunction with optical imagery (Leckie et al. 2003, Coops et al. 2004). Using tree crown delineation as the basic spatial unit to interrogate LiDAR point clouds will allow the generation of crown specific attributes on vertical structure as well as offering opportunities to better characterize species at the single tree level (Orka et al. 2012). Advanced processing of overlapping pairs of airborne digital image data can convey information regarding vertical structure. These stereo-photogrammetric approaches show promise for providing forest structural information as well as traditional attributes from the photos collected (Vastaranta et al. 2013). For individual tree level analyses, digital imagery (or scanned photos) must of be a high spatial resolution (decimeter-sided pixels). Historic analyses of archival photos are possible (St-Onge et al. 2004) although often confounded by differences in photo scale through time (Vega and St-Onge 2008).

Currently LiDAR data is collected at near-infrared wavelengths with new systems offering different and multiple wavelength options. Yu et al. (2014) provide insights regarding the use of multi-wavelength LiDAR in an operationalfocused tree detection and species identification trial. Increases in storage and computer processing power will offer unique opportunities to build and apply refined algorithms over increasingly large areas in a timely and robust fashion. Besides current and growing suite of very high spatial resolution satellites, new generation cube-sats will offer data with both fine spatial resolution and high revisit rates (Butler 2014). Overall, as a data source, LiDAR remains positioned to provide the most incremental benefit to tree crown studies, with growth and change detection becoming possible as second LiDAR passes over a given area become more common. It follows that sufficient time between the LiDAR overpasses is required for detectable levels of growth to occur (as illustrated in Wulder et al. 2008, Fig. 6). While LiDAR is increasingly considered operational, notable gains in attribute estimates are being made through improved and refined modeling approaches (e.g., Bouvier et al. 2015).

The variables used to describe the tree crown in the CFAR project (and in most other studies) are highly simplified (crown width, length, and ratio). Tree crowns, on the other hand, are highly complex and variable three-dimensional structures, and the use of simple variables entails a large loss of information. It has been pointed out, for instance, that not all living branches contribute equally to the stem, so "it is unrealistic to measure crown size or length and expect to arrive at a statistical correlation between these measures and wood growth on the stem" (Larson 1969). Cortini et al. (2013) found that specifying an effective crown length (63\% of the full crown length) improved models of the distribution of ring area along the stem. The effective crown length may be related to the proportion of the crown that is exposed to direct sunlight. Individual tree growth is strongly related to sunlit crown area (Wyckoff and Clark 2005), which can be estimated using airborne LiDAR (Nakajima et al. 2008).

More detailed descriptions of the distribution and activity of the foliage in crowns could be achieved by using an expanded variable set with higher dimensionality (Biging and Gill 1997, Ishii and Wilson 2001). Laser scanning has potential to capture this additional detail (Kato et al. 2009). The scope for improvement in model predictive ability with more detailed predictor variables is unknown, however better model performance may depend as much on better understanding of the functional and structural influences on fibre attributes as on a richer predictor variable set.

\section{Individual tree versus area based relationships}

The CFAR project functioned at the resolution of individual trees similar to most investigations of wood quality. Decision-makers in forest management and operations, however, typically do not need information at this fine scale of resolution. Although it is certainly possible to aggregate finer scale information to coarser scales, the question naturally arise whether it would be more effective to simply develop models at a coarser scale of resolution using remote sensing or other data. Models to estimate mean DBH from aerial laser scan- 
ning metrics have been developed in a number of jurisdictions (e.g., Woods et al. 2011). Models to predict additional fibre attributes, including average wood density, microfibril angle, fibre dimensions and strength properties have recently been developed for grid cells 400 to $500 \mathrm{~m}^{2}$ in area using aerial laser scanning data (Hilker et al. 2013, Luther et al. 2013).

These area-based relationships provide moderately accurate predictions of mean fibre attributes at the scale of the grid cells. Individual tree based relationships have the potential, which has not yet been confirmed, to provide greater accuracy when aggregated to grid cells of similar areas. If individual tree model bias is low, prediction error at the individual tree scale will be averaged out at the area scale. Furthermore, individual tree based relationships inherently provide more information about variation among trees than area based relationships.

A possible disadvantage with the use of area based relationships with remotely sensed predictors is that the model parameters and even the model structure developed for one location may not be transferrable to another location. Because the process of wood formation is regulated by functional requirements of individual trees, the likelihood of developing general models with a foundation in structure and function is greater at the individual tree than at the area scale. Future efforts to assess fibre attributes from remote sensing data may benefit from the implementation of hierarchical models. For example, coupling tree-level models with landscape-scale models would make effective use of costly fibre attribute data (Groot and Luther 2015).

\section{Conclusion}

The CFAR project demonstrated that it is possible to develop models to predict some fibre attributes from the crown characteristics of individual trees. Predictability was related to the dimensionality of the fibre attributes. Models developed for zero-dimensionality fibre attributes (e.g., $\mathrm{DBH}$, maximum branch diameters) had RMSE of $10 \%$ to $15 \%$ of mean values. Models for sapwood area (i.e., one-dimensional fibre attribute), described longitudinal patterns also with RMSE of 10\% to $15 \%$ of mean values for the best models. Models of current ring area (i.e., two-dimensional fibre attribute) described longitudinal patterns with RMSE of $15 \%$ of mean values for the best models. The values of some two-dimensional fibre attributes and all three-dimensional fibre attributes vary with the radial distance since the wood nearer the pith was formed further in the past. Consequently, current crown characteristics cannot be used as predictors of fibre attributes closer to the pith. Furthermore, crown characteristics have been shown to be not influential on current values of wood density, which appears to be mainly regulated by hydraulic and biomechanical constraints.

There are reasonable prospects for further research to address the temporal problem posed by two- and threedimensional fibre attributes, and to increase understanding of the influences on fibre attributes such as wood density. For example, more detailed descriptions of the distribution and activity of foliage in tree crowns could be achieved by using an expanded variable set which could be captured by laser scanning. The evolution of remote sensing technology also provides great potential for describing tree crowns more accurately.
The CFAR project provided answers at the resolution of individual trees and finer while forest managers usually need information at coarser scales. A common question is if the models developed should be at a coarser scale of resolution by using remote sensing or other data. However, individual tree based relationships should have the potential to provide greater accuracy when applied to larger areas since wood formation is regulated by the functional requirements of individual trees. Moreover, area based models developed using remotely sensed predictors may have the disadvantage of not being transferrable to another location.

\section{References}

Amarasekara, H. and M.P. Denne. 2002. Effects of crown size on wood characteristics of Corsican pine in relation to definitions of juvenile wood, crown formed wood and core wood. Forestry 75 : 51-61.

Axelsson, P. 1999. Processing of laser scanner data - algorithms and applications. ISPRS J. Phot. \& Rem. Sens. 54: 138-147.

Balenović, I., A. Jazbec, H. Marjanović, E. Paladinić and D. Vuletić. 2015. Modeling tree characteristics of individual black pine (Pinus nigra Arn.) trees for use in remote sensing-based inventory. Forests 6: 492-509.

Belward, A.S. and J.O. Skøien. 2014. Who launched what, when and why: trends in global land-cover observation capacity from civilian earth observation satellites. ISPRS J. Phot. \& Rem. Sens. Available online 28 April 2014, not yet paginated. doi:10.1016 /j.isprsjprs.2014.03.009

Bentley, L.P., J.C. Stegen, V.M. Savage, D.D. Smith, E.I. von Allmen, J.S. Sperry, P.B. Reich and B.J. Enquist. 2013. An empirical assessment of tree branching networks and implications for plant allometric scaling models. Ecol. Lett. 16: 1069-1078.

Bertram, J.E.A. 1989. Size-dependent scaling in branches: the mechanical design of trees revealed. Trees 4: 241-253.

Berninger, F., M. Menuccini, E. Nikinmaa, J. Grace and P. Hari. 1995. Evaporative demand determines branchiness of Scots pine. Oecologia 102: 164-168.

Bi, H., J.C. Fox, Y. Li, Y. Lei and Y. Pang. 2012. Evaluation of nonlinear equations for predicting diameter from tree height. Can. J. For. Res. 42: 789-806.

Biging, G.S. and S.J. Gill. 1997. Stochastic models for conifer tree crown profiles. For. Sci. 43: 25-34.

Blanchette, D., R.A. Fournier, J. E. Luther and J.-F. Côté. 2015. Predicting wood fibre attributes using local-scale metrics from terrestrial LiDAR data: A case study of Newfoundland conifer species. For. Ecol. Manage. 347: 116-129.

Bouvier, M,. S. Durrieu, R.A. Fournier and J.-P. Renaud. 2015. Generalizing predictive models of forest inventory attributes using an area-based approach with airborne LiDAR data. Rem. Sens. Env. 156: 322-334.

Brandeis, T.J., K.C. Randolph and M.R. Strub. 2009. Modelling Caribbean tree stem diameters from tree height and crown width measurements. Math. Comput. For. Nat.-Res. Sci. 1: 78-85.

Butler, D. 2014. Many eyes on Earth: Swarms of small satellites set to deliver close to real-time imagery of swathes of the planet. Nature 505: 143-144.

Canadian Wood Fibre Centre. 2010. The principal attributes of Canadian wood fibre. Natural Resources Canada. 18 p.

Chen, Q., D. Baldocchi, P. Gong and M. Kelly. 2006. Isolating individual trees in a savanna woodland using small footprint lidar data. Photogram. Engin. \& Rem. Sens. 72(8): 923-932.

Coops, N.C., M.A. Wulder, D. Culvenor and B. St-Onge. 2004. Comparison of forest attributes automatically extracted from high resolution and optical and lidar data, Can. J. Remote Sens. 30(6): 855-866. 
Cortini, F., C.A. Filipescu, A. Groot, D.A. MacIsaac and T. Nunifu. 2011. Regional models of diameter as a function of individual tree attributes, climate and site characteristics for six major tree species in Alberta, Canada. Forests 2: 814-831.

Cortini, F., A. Groot and C. Filipescu. 2013. Models of the longitudinal distribution of ring area as a function of tree and stand attributes for four major Canadian conifers. Ann. For. Sci. 70: 637-648.

Cortini, F., A. Groot, Q. Tong and I. Duchesne. 2014. Ring-level models for predicting wood and fibre properties of Abies balsamea. Wood Sci. Technol. 48: 1181-1196.

Culvenor, D.S. 2003. Survey of techniques for extracting individual tree information from high spatial resolution imagery. In Remote sensing of forest environments: concepts and case studies. M.A. Wulder and S.E. Franklin (Eds.), pp. 225-279 (Boston: Kluwer Academic Publishers).

Cruickshank, M., I. Cameron, A. Groot, J. Stewart and J. Goudie. in review. Models of the vertical distribution of sapwood area in lodgepole pine and western hemlock in western Canada (submitted to Forest Science)

Dean, T.J. and J.N. Long. 1986. Variation in sapwood area - leaf area relations within two stands of lodgepole pine. For. Sci. 32: 749-758.

Domec, J.C. and B.L. Gartner. 2002. How do water transport and water storage differ in coniferous earlywood and latewood? J. Exp. Bot. 53: 2369-2379.

Downes, G.M., R. Wimmer and R. Evans. 2002. Understanding wood formation: gains to commercial forestry through tree-ring research. Dendrochronologia 20: 37-51.

Duchateau, E., F. Longuetaud, F. Mothe, C. Ung, D. Auty and A. Achim. 2013. Modelling knot morphology as function of external tree and branch attributes. Can. J. For. Res. 43: 266-277.

Duncanson, L.I., B.D. Cook., G.C. Hurtt and R.O. Dubayah 2014. An efficient, multi-layered crown delineation algorithm for mapping individual tree structure across multiple ecosystems. Rem. Sens. Env. 154: 378-386.

Dutilleul, P., M. Herman and T. Avella-Shaw. 1998. Growth rate effects on correlations among ring width, wood density, and mean tracheid length in Norway spruce (Picea abies). Can. J. For. Res. 28: 56-68.

Eloy, C. 2011. Leonardo's rule, self-similarity and wind-induced stresses in trees. Phys. Rev. Lett. 107: 258101.

Eriksson, D., H. Lindberg and U. Bergsten. 2006. Influence of silvicultural regime on wood structure characteristics and mechanical properties of clear wood in Pinus sylvestris. Silva Fennica 40: 743-762.

Evans, R. 2006. Wood stiffness by X-ray diffractometry. In: Stokke, D. and L. Groom (ed.) characterisation of the cellulosic cell wall, Chapter 11. Proceedings of the Workshop 25-27 August 2003, Grand Lake,Colorado, USA. Sothern Research Station, University of Iowa and the Society of Wood Science and technology. Blackwell Publishing.

Farrar, J.L. 1961. Longitudinal variation in the thickness of the annual ring. For. Chron. 37: 323-330, 349.

Filipescu, C.A., A. Groot, D. MacIsaac, M.G. Cruickshank and J.D. Stewart. 2012. Prediction of diameter using height and crown attributes: A case study. West. J. Appl. Forestry 27: 20-35.

Franceschini, T., F. Longuetaud, J.-D. Bontemps, O. Bouriaud, B.D. Caritey and J.-M. Leban. 2013. Effect of ring width, cambial age, and climatic variables on the within-ring wood density profile of Norway spruce Picea abies (L.) Karst. Trees 27: 913-925.

Garber, S.M. and D.A. Maguire. 2005. Vertical trends in maximum branch diameter in two mixed-species spacing trials in the central Oregon Cascades. Can. J. For. Res. 35: 295-307.

Gartner, B.L., E.M. North, G.R. Johnson and R. Singleton. 2002. Effects of live crown on vertical patterns of wood density and growth in Douglas-fir. Can. J. For. Res. 32: 439-447.
Gilmore, D. W. and R.S. Seymour. 1996. Alternative measures of stem growth efficiency applied to Abies balsamea from four canopy positions in central Maine, USA. For. Ecol. Manage. 84: 209-218.

Gjerdrum, P. and B. Eikenes. 2014. A model for spatial wood density gradients in Norway spruce stems and stochastic between-stem dissimilarities for basic and dry density. Wood Sci. Technol. 48: 71-84.

Gonzalez-Benecke, C.A., S.A. Gezan, L.J. Samuelson, W.P. Cropper Jr., D.J. Leduc and T.A. Martin. 2014. Estimating Pinus palustris tree diameter and stem volume from tree height, crown area and stand-level parameters. J. For. Res. 25: 43-52.

Groot. A. and F. Cortini. in review. Tree slenderness and relative height interact with ring width to influence wood density in Abies balsamea and Picea glauca.

Groot, A. and J.E. Luther. 2015. Hierarchical analysis of balsam fir and black spruce wood density in Newfoundland. Submitted to Can. J. For. Res., in press.

Groot, A. and J.-P. Saucier. 2008. Volume increment efficiency of Picea mariana in northern Ontario, Canada. For. Ecol. Manage. 255:1647-1653.

Groot, A. and R. Schneider. 2011. Predicting maximum branch diameter from crown dimensions, stand characteristics and tree species. For. Chron. 87: 542-551.

Hacke, U.G., J.S. Sperry, W.T. Pockman, S.D. Davis and K.A. McCulloh. 2001. Trends in wood density and structure are linked to prevention of xylem implosion by negative pressure. Oecologia 126: 457-461.

Hari, P., P. Heikinheimo, A. Mäkelä, L. Kaipaianinen, E. Korpilahti and J. Samela. 1986. Trees as a water transport system. Silva Fennica 20: 205-210.

Hilker, T., G.W. Frazer, N.C. Coops, M.A. Wulder, G.J. Newnham, J.D. Stewart, M. van Leeuwen and D.S. Culvenor. 2013. Prediction of wood fibre attributes from LiDAR-derived forest canopy indicators. For. Sci. 59: 231-242.

Holtzscher, M.A. and B.L. Lanford. 1997. Tree diameter effects on cost and productivity of cut-to-length systems. For. Prod. J. 47: 25-30. Hyyppä, J. X. Yu, H. Hyyppa, M. Vastaranta, M. Holopainen, A. Kukko, H. Kaartinen, A. Jaakkola, M. Vaaja, J.O. Koskinen and P. Alho. 2012. Advances in forest inventory using airborne laser scanning. Rem. Sens. 4(5): 1190-1207.

Ishii, H. and M.E. Wilson. 2001. Crown structure of old-growth Douglas-fir in the western Cascade Range, Washington. Can. J. For. Res. 31: 150-1261.

Jozsa, L.A. and G.R. Middleton. 1994. A discussion of wood quality attributes and their practical implications. Special Publication No. SP-34, Forintek Canada Corp., Vancouver, BC.

Jyske, T., H. Mäkinen and P. Saranpää. 2008. Wood density within Norway spruce stems. Silva Fennica 42: 439-455.

Kato, A., L.M. Moskal, P. Schiess, M.E. Swanson, D. Calhoun and W. Stuetzle. 2009. Capturing tree crown formation through implicit surface reconstruction using airborne LiDAR data. Remote Sens. Env. 113: 1148-1162.

Kärkkäinen, M. 1984. Effect of tree social status on the basic density of Norway spruce. Silva Fennica 18: 115-120.

Ke, Y. and L.J. Quackenbush. 2007, Forest species classification and tree crown delineation using QuickBird imagery. In Proceedings of the 2007 ASPRS Annual Conference, 7-11 May, Tampa, FL (Bethesda, MD: American Society for Photogrammetry and Remote Sensing).

Ke, Y. and L.J. Quackenbush. 2011. A review of methods for automatic individual tree-crown detection and delineation from passive remote sensing. Intern. J. Rem. Sens. 32 (17): 4725-4747.

Kijidani, Y., T. Hamazuna, S. Ito, R. Kitahara, S. Fukuchi, N. Mizoue and S. Yoshida. 2010. Effect of height-to-diameter ratio on stem stiffness of sugi (Cryptomeria japonica) cultivars. J. Wood Sci. 56: $1-6$. 
Lachenbruch, B., J.R. Moore and R. Evans. 2011. Radial variation in wood structure and function in woody plants, and hypotheses for its occurrence. p. 121-164. In Meinzer, F.C., Lachenbruch, B. and T.E. Dawson. (eds.). Size- and age-related changes in tree structure and function. Springer, Dordrecht. $510 \mathrm{p}$.

Larocque, G.R. and P.L. Marshall. 1995. Wood relative density development in red pine (Pinus resionsa Ait.) as affected by different initial spacings. For. Sci. 41: 709-728.

Larson, P.R. 1963. Stem form development of forest trees. For. Sci. Monogr. 5: 1-42.

Larson, P.R. 1969. Wood formation and the concept of wood quality. Yale University, Sch. Forestry. Bulletin No. 74. 54 p.

Leckie, D., F. Gougeon, D. Hill, R. Quinn, L.Armstrong and R. Shreenan. 2003. Combined high-density LiDAR and multispectral imagery for individual tree crown analysis. Can. J. Rem. Sens. 29: 633-649.

Lei, Y.C., S.Y. Zhang and Z. Jiang. 2005. Models for predicting lumber bending MOR and MOE based on tree and stand characteristics in black spruce. Wood Sci. Technol. 39: 37-47.

Lindström, H. 1966a. Basic density in Norway spruce. Part I. A literature review. Wood Fiber Sci. 28: 15-27.

Lindström, H. 1966b. Basic density in Norway spruce. Part II. Predicted by stem taper, mean growth ring width, and factors related to crown development. Wood Fiber Sci. 28: 240-251.

Lindström, H. 1966c. Basic density in Norway spruce. Part III. Development from pith outwards. Wood Fiber Sci. 28: 391-405.

Lowell, E.C., C.L. Todoroki, D.P. Dykstra and D.G. Briggs. 2014. Linking acoustic velocity of standing Douglas-fir trees to veneer stiffness: A tree-log-product study across thinning treatments. New Zealand J. For. Sci. 44: 1-16.

Luther, J.E., R. Skinner, R.A. Fournier, O.R. van Lier, W.W. Bowers, J.-F. Coté, C. Hopkinson and T. Moulton. 2013. Predicting wood quantity and quality attributes of balsam fir and black spruce using airborne laser scanner data. Forestry 87: 313-326.

Mackenzie, J. and G. Bruemmer. 2009. Enhancing Canada's forest fibre. For. Chron. 85: 353-354.

Mäkinen, H., T. Jaakkola, R. Piispanen and P. Saranpää. 2007. Predicting wood and tracheid properties of Norway spruce. For. Ecol. Manage. 241: 175-188.

Mansfield, S.D., R. Parish, J.W. Goudie, K.-Y. Kang and P. Ott. 2007. The effects of crown ratio on the transition from juvenile to mature wood production in lodgepole pine in western Canada. Can. J. For. Res. 37: 1450-1459.

Mason, E. 2008. Influence of silviculture, genetics and environment on radiata pine corewood properties: Results from recent studies and a future direction. N. Z. J. For. 53: 26-31.

Mitchell, K. J. 1975. Dynamics and simulated yield of Douglas-fir. For. Sci. Monogr. 17, 39 p.

Nakajima, T., Y. Hirata, T. Hiroshima, N Furuya and S. Tatsuhara. 2008. An analysis of the relationships between tree growth and crown information derived from airborne LiDAR data. p. 498-507 In: Hill R.A., J. Rosette, and J. Suárez (eds). Proceedings of SilviLaser 2008: 8th International Conference on LiDAR Applications in Forest Assessment and Inventory. September 2008. Edinburgh, UK.

Niklas, K.J. and H.-C. Spatz. 2010. Worldwide correlations of mechanical properties and green wood density. Am. J. Bot. 97: 1587-1594.

Ottorini, J. M., N. Le Goff and C. Cluzeau. 1996. Relationships between crown dimensions and stem development in Fraxinus excelsior. Can. J. For. Res. 26: 394-401.

Panshin, A.J. and C. de Zeuw. 1970. Textbook of Wood Technology. McGraw-Hill, New York, 705 p.

Ørka, H. O. T. Gobakken, E. Naesset, L. Ene and V. Lien. 2012. Simultaneously acquired airborne laser scanning and multispectral imagery for individual tree species identification. Can. J. Rem. Sens. 38(02): 125-138.
Pitt, D. and J. Pineau. 2009. Forest inventory research at the Canadian Wood Fibre Centre: Notes from a research coordination workshop, June 3-4, 2009, Pointe Claire, QC. For. Chron. 85: 859-869.

Pokharel, B., J. Dech, A. Groot and D. Pitt. 2014. Ecosite-based predictive modeling of black spruce (Picea mariana) wood quality attributes in boreal Ontario. Can. J. For. Res. 44 (5): 465-475.

Popescu, S.C. 2007. Estimating biomass of individual pine trees using airborne LiDAR. Biomass Bioenerg. 31: 646-655.

Pouliot, D.A., D.J. King, F.W. Bell and D.G. Pitt. 2002. Automated tree crown detection and delineation in high-resolution digital camera imagery of coniferous forest regeneration. Rem. Sens. Environ. 82: 322-334.

Pressler, M.R. 1864. Das Gesetz der Stammbildung. Arnoldische Buchhandlung, Leipzig, $153 \mathrm{p}$.

Repola, J. 2006. Models for vertical wood density of Scots pine, Norway spruce and birch stems, and their application to determine average wood density. Silva Fennica 40: 673-685.

Richter, J. P. (translator) 1888. The notebooks of Leonardo Da Vinci. Public Domain Book.

Roth, B.E., X. Li, D.A. Huber and G.F. Peter. 2007. Effects of management intensity, genetics and planting density on wood stiffness in a plantation of juvenile loblolly pine in the southeastern USA. For. Ecol. Manage. 246: 155-162.

Saranpää, P. 2003. Wood density and growth. In: Wood Quality and its Biological Basis. J.R. Barnett and G. Jeronimidis (eds). Blackwell Publishing \& CRC Press, Boca Raton. pp. 87-117.

St-Onge, B., J. Jumelet, M. Cobello and C. Vega. 2004. Measuring individual tree height using a combination of stereo photogrammetry and LiDAR. Can. J. For. Res. 34: 2122-2130.

Taylor, A.M., B.L. Gartner and J.J. Morrell. 2002. Heartwood formation and natural durability-a review. Wood Fibre Sci. 34: 587-611.

Van Leeuwen, M., T. Hilker, N.C. Coops, G. Frazer, M.A. Wulder, G.J. Newnham and D.S. Culvenor. 2011. Assessment of standing wood and fiber quality using ground and airborne laser scanning: A review. For. Ecol. Manage. 261: 1467-1478.

Vastaranta, M., M. Holopainen, X. Yu, J. Hyyppä, A. Mäkinen, J. Rasinmäki, T. Melkas, H. Kaartinen and H. Hyyppä. 2011. Effects of individual tree detection error sources on forest management planning calculations. Rem. Sens. 3(8): 1614-1626.

Vastaranta, M.; M.A. Wulder, J.C. White, A. Pekkarinen, S. Tuominen, C. Ginzler, V. Kankare, M. Holopainen, J. Hyyppä and H. Hyyppä. 2013. Airborne laser scanning and digital stereo imagery measures of forest structure: Comparative results and implications to forest mapping and inventory update. Can. J. Rem. Sens. 39(5): 382-395.

Vega, C. and B. St-Onge. 2008. Height growth reconstruction of a boreal forest canopy over a period of 58 years using a combination of photogrammetric and LiDAR models. Rem. Sens. Env. 112: 1784-1794.

Vincent, M.,C. Krause and A. Koubaa. 2011. Variation in black spruce (Picea mariana (Mill.) BSP wood quality after thinning. Ann. For. Sci. 68: 1115-1125.

Waring, R.H., P.E. Schroeder and R. Oren. 1982. Application of pipe model theory to predict canopy leaf area. Can. J. For. Res. 12: 556-560.

Warren, E., R.G.B. Smith, L.A. Apiolaza and J.C.F. Walker. 2009. Effect of stocking on juvenile wood stiffness for three Eucalyptus species. New Forests 37: 241-250.

Watt, M.S. and M.U.F. Kirschbuam. 2011. Moving beyond simple allometric relationships between tree height and diameter. Ecol. Mod. 222: 3910-3916.

Wegner, T., K.E. Skog, P.J. Ince and C.J. Michler. 2010. Uses and desirable properties of wood in the 21st century. J. For. 108: 401-408. Woodcock, D.W. and A.D. Shier. 2002. Wood specific gravity and its radial variations: The many ways to make a tree. Trees 16: 437-443. 
Woodcock, D.W. and A.D. Shier. 2003. Does canopy position affect wood specific gravity in temperate forest trees? Ann. Bot. 91: 529-537.

Woods, M., D. Pitt, M. Penner, K. Lim, D. Nesbitt, D. Etheridge and P. Treitz. 2011. Operational implementation of a LiDAR inventory in Boreal Ontario. For. Chon. 87: 512-528.

Wulder, M., R. Hall, N. Coops and S. Franklin. 2004. High spatial resolution remotely sensed data for ecosystem characterization. BioScience 54: 511-521.

Wulder, M.A., C.W. Bater, N.C. Coops, T. Hilker and J.C. White. 2008. The role of LiDAR in sustainable forest management. For Chron. 84: 807-826.

Wulder, M. A., N.C. Coops, A.T. Hudak, F. Morsdorf, R. Nelson, G. Newnham, and M. Vastaranta. 2013. Status and prospects for LiDAR remote sensing of forested ecosystems. Can. J. Rem. Sens. 39(s1): S1-S5
Wyckoff, P.H. and J.S. Clark. 2005. Tree growth prediction using size and exposed crown area. Can. J. For. Res. 35: 13-20.

Yu, X., P. Litkey, J. Hyyppä, M. Holopainen, and M. Vastaranta. 2014. Assessment of low density full-waveform airborne laser scanning for individual tree detection and tree species classification. Forests 5(5): 1011-1031.

Zagalikis, G., A.D. Cameron and D.R. Miller. 2005. The application of digital photogrammetry and image analysis techniques to derive tree and stand characteristics. Can. J. For. Res. 35: 1224-1237. Zhang, S.Y. and A. Koubaa. 2008. Softwoods of eastern Canada: Their silvics, characteristics and end uses. FPInnovations-Forintek Division, Special Publication SP-526E.

Zhu, J.Y., C.T. Scott, K.L. Scallon and G.C. Myers. 2007. Effects of plantation density on wood density and anatomical properties of red pine (Pinus resinosa Ait.). Wood Fiber Sci. 39: 502-512. 